\title{
Opportunities for Method Competence Development of Mathematics Teachers: The Role of Participation in Competitions with Colleagues
}

\author{
Olha Matiash, Liubov Mykhailenko* \\ Department of Algebra and Mathematics Teaching Methods, \\ Vinnytsia Mykhailo Kotsiubynskyi State Pedagogical University, Ukraine \\ Received October 18, 2019; Revised January 27, 2020; Accepted February 7, 2020
}

Copyright $\odot 2020$ by authors, all rights reserved. Authors agree that this article remains permanently open access under the terms of the Creative Commons Attribution License 4.0 International License

\begin{abstract}
The article contains explanations of the importance of developing the competence of teachers with teaching mathematics and introduces the idea of constructive approximation of the methodical activity of school teachers and lecturers of pedagogical universities. It describes certain features of the Ukrainian system of methodical training of future mathematics teachers at pedagogical universities. The objective of the study is to experimentally discover the influence of teachers' participation in special geometry teaching competitions on the methodological development of practicing and future mathematics teachers. For the purposes of the study, the Vinnytsia State Pedagogical University hosted a competition of geometry teaching methodological findings for practicing teachers and a methodological skills contest for future math teachers in 2017, 2018, and 2019. We surveyed 32 participants of the above competitions. Practicing math teachers have laid stress upon the high quality of discussions on current problems of teaching geometry, new opportunities to share the experience gained, the high level of expertise and recognition of their own ideas about teaching geometry within the cooperation with the Pedagogical University organized by us. Future mathematics teachers have indicated the growing interest in future methodical activities at school, decided upon their own own aspirations for methodological development. The main conclusions: the educational environment for training the future mathematics teachers at the university should promptly respond to the new requirements for methodical performance of a teacher of the modern school; future math teachers have more opportunities for methodological development in specially created conditions of communication with experienced practicing teachers; practicing math teachers have more opportunities for methodological self-development in the process of active
\end{abstract}

discussion of methodological issues with future teachers, lecturers of pedagogical universities, and scientists in the field of mathematics teaching methodology. We bring your attention to topicality of the problem of math teachers' creative approach to teaching, their willingness to comprehend, analyze and adopt innovations.

Keywords Development of Method Competence of a Teacher of Mathematics, Collaboration of Teachers, Formation of Method Competence of a Future Teacher, Partnership of School and University, Professional Competitions

\section{Introduction}

Much of the research in mathematics education suggests a mismatch between teachers' beliefs in teaching mathematics and their actual practice in the classroom [1]. Based on the modern reforms in mathematical education, there are new concepts for the assessment of pedagogical activities of working teachers: "conventional teacher" and "new teacher". One of the pressing problems in the preparation of a "new teacher" in Ukraine is the lack of effective interaction between schools and pedagogical universities in organizing practical training for future teachers. In this context, we are interested in the experience of American educators in organizing the training of future teachers in vocational schools. We know from the literature [2] that American schools of professional development are innovative institutions created through partnerships between colleges of education of universities and secondary schools of various levels. In the School of Professional Development, as a partner of the university (the center of theory) and the 
general education school (center of practice), the program of practical training of future teachers is developed and implemented jointly with teachers of the college of education and teachers of schools [2-8].

Professional development programs are offered as effective mechanisms for creating a "new" teacher. Valoyes-Chávez [9] explores the ways in which a teacher of mathematics in the higher school gives a new meaning to a teacher of mathematics in the context of professional development programs aimed at the implementation of instructions for solving problems. Professional teaching experience provides teachers with opportunities to improve their understanding of mathematics content and teaching practices. It is relevant to explore different ways of engaging teachers in professional development and how these approaches can enable the field to expand these efforts in a sustainable manner [10]. We have a particular scientific interest in the possible forms of effective interaction between schools and pedagogical universities, which contribute to the professional development of teachers. In order to identify new forms of partnership between teachers of mathematics and teachers of higher education institutions, we considered some indicators of the professional development of mathematics teachers: motivation for professional development; ability to individually-creative technology of methodical activity; readiness to present new ideas; readiness for active professional interaction with colleagues. The idea was to test the impact on these indicators of specially organized competitions of teachers and future teachers in methodical skills. It should be noted that promoting the professional development of a teacher is an ambitious and difficult job [11].

The objectives of this article is to present the results of our experimental work related to building a partnership between teachers of mathematics and teachers of higher educational institutions where future teachers of mathematics are trained. In our experimental studies, we sought answers to the following questions: Has her/his participation in competitions with colleagues in the areas of methodological activities a positive impact on the methodological development of a teacher of mathematics? How does the possibility of partnership between teachers of mathematics and university departments for future teachers of mathematics influence the conditions of methodological training of future teachers of mathematics? How does students' participation in the competitions in the areas of methodological activities of teachers of mathematics influence them? At the same time, this article aims to reveal certain traditions and new trends of Ukrainian pedagogical education, in particular in solving the problem of professional development of working teachers of mathematics and improving the methods and means of methodological training of future teachers of mathematics.

\section{Materials and Methods}

We understand the method competence of a teacher of mathematics as a system of his/her methodological knowledge, skills and beliefs, as well as the experience of effective solution of specific methodological problems in teaching mathematics to students. As an example, we will specify some methodological problems in teaching mathematics to students: to explain a new mathematical concept to students; to find out the level of learning by students of a certain training subject; to create conditions for students to understand the solution of a specific mathematical problem; to awaken students' interest in studying a certain academical subject; to prepare and conduct an effective lesson in mathematics, etc. It is obvious that in addition to method competence, the teacher of mathematics should have an appropriate level of mathematical competence, pedagogical competence, information competence, communicative competence, etc.

We distinguish the following basic modern requirements to methodological activities of a teacher of mathematics:

- rethinking the place and role of mathematics in the formation of student's personality in modern society;

- existence of beliefs in methodological activities;

- creative methodological activities, commitment to understanding, analysis and perception of innovation.

Admission to the profession of teacher is only possible in Ukraine subject to obtaining diploma after at least four years of training in the specialty in a higher education institution. The system of methodological training of future teachers of mathematics at the university should provide effective conditions for the formation and development of readiness and ability of future teachers to effective methodological activities. Results of the analyzed pedagogical research make an emphasis on:

- how to prepare teachers to become facilitators of collaboration in groups. Working together in groups is often the context for significant individual learning outcomes [12];

- practical approaches to teachers training help to bridge the distance between university courses and field experience. Future teachers are trained to implement innovative learning strategies studied through research. The positive impact of video and practical course on the methods of teaching mathematics to future teachers and the analysis of their own training is proved [13].

Solving the problem of improving the quality of methodological training of future teachers of mathematics is influenced by many different factors. Among them, in the context of our research, we highlight the level of motivation for the development of method competence through active cooperation with other teachers of 
mathematics, as well as participation in various professional competitions. The idea of development of active collaboration between working teachers of mathematics and departments of higher education institutions which provide training for future teachers of mathematics is relatively new for Ukrainian mathematical education. In our opinion [14], the gap between the school and pedagogical university should be bridged as constructively as possible in order to implement this idea. Such a rapprochement is necessary for several reasons: the educational environment of a future teacher of mathematics at the university should respond quickly to the now proclaimed adjustment of the methodological activities of the teacher of modern school; students will have more opportunities to observe the actual school practice, to communicate with practical teachers, to form correct ideas about the modern student, etc.; teachers will have more opportunities for methodological self-development in the process of active discussion of methodological problems with scientists in the field of mathematics teaching methods.

The research procedure was based on the usage of the following methods and methodologies: pedagogical experiment, pedagogical observation, survey.

In order to find answers to the questions: In which forms is the partnership between teachers of mathematics and teachers of higher pedagogical educational institutions which provide training for future teachers of mathematics effective? Has her/his participation in competitions with colleagues in the areas of methodological activities a positive impact on the methodological development of a teacher of mathematics? How does the possibility of partnership between teachers of mathematics and university departments for future teachers of mathematics influence the conditions of methodological training of future teachers of mathematics? How does students' participation in the competitions in the areas of methodological activities of teachers of mathematics influence them?, we were conducting a pedagogical experiment for three years (2017-2019), which is described in this article in the form of two episodes.

Episode 1. Tournament of Methodological Findings in teaching geometry to students for working teachers of mathematics is a form of testing, as an interactive competition, pedagogical experience of teachers of mathematics to solve problems of formation of geometric competencies of students. Methodological findings in teaching geometry to students within this Tournament were: original methodological developments aimed at overcoming the problems of teaching geometry to students; original design of geometry lessons; original thematic compositions of geometric problems; etc. The mission of the event was to support the creative activity of teachers of mathematics of Ukraine through disclosure and recognition of their methodological achievements, encouraging vigorous professional activities, conscious self-improvement in solving urgent methodological problems of improving the efficiency of teaching geometry in school. The aim of the Tournament was to identify the level of method and communicative competence of teachers of mathematics in teaching geometry to students and to create conditions for recognition, generalization and dissemination of the best achievements in geometry teaching experience of Ukrainian practical teachers. Requirements for the competition paper (Department of Algebra and Mathematics Teaching Methods, nd, About the Olympics [15]): an original idea of solving one of the problems of teaching geometry to students; description or video of the relevant fragment of pedagogical experience. Each registered competition paper would participate in the extramural stage of the Tournament: it would be reviewed by at least three members of the Tournament jury. According to the results of the review, the number of competition participants of the intramural stage of the Tournament would be determined. Intramural stage of the Tournament: discussion of methodical findings in teaching geometry to students based on the presentation of the winners of the extramural stage of the Tournament. During the three Tournament runnings in 2017, 2018 and 2019 , it was attended by 48 teachers of mathematics in the extramural stage and 32 of them in the intramural stage of the Tournament. 18 teachers of mathematics were recognized the winners of the Tournament and awarded.

Episode 2. Necessary conditions for the formation of method competence of future teachers of mathematics in the context of our study include a variety of forms and methods of acquiring methodological experience in teaching mathematics to students. In addition to the traditional teaching practice at school, we have tested laboratory classes on methods of teaching mathematics, at which students play the role of a teacher of mathematics in different types of lessons in the form of a quasi-professional game. Based on the detailed analysis, the teacher of methods of teaching mathematics would characterize methodological activities of a future teacher in each fragment, on the basis of which generalized guidelines recommendations on future methodological activities in teaching mathematics to students at school would be developed. Interesting results were obtained by us in the experiment of the teaching skill contest (Department of Algebra and Mathematics Teaching Methods, nd, teaching skill contest [16]) which has been held by us for several years at the Department of Algebra and Mathematics Teaching Methods of Vinnytsia Mykhailo Kotsiubynskyi State Pedagogical University for undergraduate students. Students who have shown the best results as future teachers of mathematics in laboratory classes devoted to methods of teaching mathematics would participate in the contest. The contest is held annually in the form of face-to-face competition of 6-8 participants: fragments of mathematics lessons, quiz on 
methodological and mathematical topics, presentation of methodological credo. The activity of the contest participants was evaluated by a professional jury which included practical teachers of mathematics who had achieved best results in teaching mathematics to students. In order to identify the impact of participation in the above-described competitions on the methodological development of teachers of mathematics, we used the expert evaluation method (Delphi method). The main stages of implementing the expert evaluation method in our study are: selection of experts; determining factors for the survey, conducting the survey, analyzing the results of the survey and processing the results.

In the first episode, experts were the participants of the Tournament of Methodological Findings - 32 teachers of mathematics, participants of intramural competitions of the Tournament of Methodological Findings.

In the survey sheet 10 factors were suggested: (1) relevance of any competition between the teachers of mathematics; (2) originality of the proposed form of competition between teachers of mathematics; (3) novelty of the idea of organizing such a competition between teachers of mathematics; (4) effectiveness of the proposed form of competition between teachers of mathematics for the methodological development of teachers; (5) usefulness of the proposed form of competition between teachers of mathematics to participants; (6) usefulness of the proposed form of competition between teachers of mathematics to the spectators of the Tournament of
Methodological Findings; (7) usefulness of the proposed form of competition between teachers of mathematics to encourage professional development; (8) usefulness of the proposed form of competition between teachers of mathematics to enhance the ability to individually-creative technology of methodological activities; (9) usefulness of the proposed form of competition between teachers of mathematics to improve the readiness for professional interaction with colleagues; (10) impact on your desire to continue participation in similar competitions for teachers of mathematics.

\section{Results}

The methods of mathematical statistics used by us are based on ranking. In our case, each expert assigned a rank from 10 to 1 to each factor (in descending order to determine their relative importance).

A necessary condition for reliability of the collective evaluation is sufficient consistency of the surveyed experts' opinions. To determine the consistency of group estimates, we used the concordance coefficient - overall rank correlation coefficient for a group of experts. The results of the expert survey were processed as follows (Table 1).

For each factor, we found the total rank, the average rank, based on which we determined the rank of the factor (Table 2).

Table 1. Factor evaluation ranks.

\begin{tabular}{|c|c|c|c|c|c|c|c|c|c|c|}
\hline Factor number & 1 & 2 & 3 & 4 & 5 & 6 & 7 & 8 & 9 & 10 \\
\hline Expert 1 & $\mathrm{X}_{11}$ & $\mathrm{X}_{12}$ & $\mathrm{X}_{13}$ & $\mathrm{X}_{14}$ & $\mathrm{X}_{15}$ & $\mathrm{X}_{16}$ & $\mathrm{X}_{17}$ & $\mathrm{X}_{18}$ & $\mathrm{X}_{19}$ & $\mathrm{X}_{110}$ \\
\hline Expert 2 & $\mathrm{X}_{21}$ & $\mathrm{X}_{22}$ & $\mathrm{X}_{23}$ & $\mathrm{X}_{24}$ & $\mathrm{X}_{25}$ & $\mathrm{X}_{26}$ & $\mathrm{X}_{27}$ & $\mathrm{X}_{28}$ & $\mathrm{X}_{29}$ & $\mathrm{X}_{210}$ \\
\hline$\ldots$ & $\ldots$ & $\ldots$ & $\ldots$ & $\ldots$ & $\ldots$ & $\ldots$ & $\ldots$ & $\ldots$ & $\ldots$ & $\ldots$ \\
\hline Expert 32 & $\mathrm{X}_{321}$ & $\mathrm{X}_{322}$ & $\mathrm{X}_{323}$ & $\mathrm{X}_{324}$ & $\mathrm{X}_{325}$ & $\mathrm{X}_{326}$ & $\mathrm{X}_{327}$ & $\mathrm{X}_{328}$ & $\mathrm{X}_{329}$ & $\mathrm{X}_{3210}$ \\
\hline
\end{tabular}

Table 2. Factor ranks.

\begin{tabular}{|c|c|c|c|c|c|c|c|c|c|c|}
\hline Factors & 1 & 2 & 3 & 4 & 5 & 6 & 7 & 8 & 9 & 10 \\
\hline Sum of ranks & 37 & 124 & 129 & 228 & 320 & 71 & 284 & 176 & 200 & 150 \\
\hline Average rank & 1,16 & 3,90 & 4,03 & 7,12 & 10 & 2,22 & 8,87 & 5,50 & 6,25 & 4,69 \\
\hline Rank factor & 10 & 8 & 7 & 3 & 1 & 9 & 2 & 5 & 4 & 6 \\
\hline
\end{tabular}


Thus, the following issues appeared to be most significant:

- usefulness of the proposed form of competition between teachers of mathematics to participants;

- usefulness of the proposed form of competition between teachers of mathematics to encourage professional development;

- usefulness of the proposed form of competition between teachers of mathematics to improve the readiness for professional interaction with colleagues;

- effectiveness of the proposed form of competition between teachers of mathematics for the methodological development of teachers;

- usefulness of the proposed form of competition between teachers of mathematics to enhance the ability to individually-creative technology of methodological activities.

The consistency of expert opinions was assessed using the concordance coefficient, which was calculated using the formula (1):

$$
W=\frac{12}{m^{2}\left(n^{3}-n\right)} \sum_{j=1}^{n}\left[\sum_{i=1}^{m} x_{y}-\frac{m \cdot(n+1)}{2}\right]^{2}
$$

where $m$ is the number of experts; $n$ is the number of factors.

In our case, $m=32, n=10$. The resulting value $W=0.64$, which according to the scale for rank correlation coefficients falls within the range $(0.6 ; 0.8)$, which means a good consistency of expert opinions. To check the significance of the concordance coefficient, find the actual value using the formula (2):

$$
\chi_{f}^{2}=m(n-1) \cdot W
$$

By the level of significance $\alpha$ and the number of degrees of freedom $\mathrm{q}=\mathrm{n}-1$ from the Pearson tables, find the critical value $\chi_{c r}^{2}$. If $\chi_{f}^{2}>\chi_{c r}^{2}$, then the concordance coefficient can be trusted and the conclusions derived from it are reliable.

To check the significance of the concordance coefficient, find the value of the critical point by the significance level $\alpha=0.05$ and the number of degrees of freedom $\mathrm{q}=10-1=9$. Using the Pearson table, find the value $\chi_{c r}^{2}(9 ; 0,05)=10$. Since $\chi_{f}^{2}>\chi_{c r}^{2}$, it is possible to draw a conclusion about the significance of the concordance coefficient. Thus, the conclusions obtained from our experimental studies are reliable.

The results of the experiment, observation and expert survey showed that participation of teachers of mathematics in competitions on teaching geometry to students has a positive impact on indicators of professional development of teachers of mathematics such as motivation for professional development; ability to individually creative technology of methodological activity; readiness to present new ideas; readiness for active professional interaction with colleagues.

In the settings of cooperation organized with the Pedagogical University, practical teachers of mathematics note the high quality of discussions on current problems of teaching geometry to students, new opportunities for sharing experience, expertise and recognition of their own ideas about teaching mathematics to students.

\section{Discussion}

In search of ways to establish constructive collaboration between working teachers of mathematics and teams of teachers who prepare future teachers of mathematics, we, in the settings of a real pedagogical experiment, tested the effectiveness of forms of collaboration such as organization and running of competitions in the methods of teaching mathematics. The "Tournament of Methodological Findings in Teaching Geometry to Students" conducted by us for working teachers of mathematics and "Teaching Skill Contest" for future teachers of mathematics have led to the conclusion about improving the conditions of development of method competence of working teachers of mathematics and the conditions of formation of method competence of future teachers of mathematics.

Episode 1. In the methodological literature, there are examples of partnership between different educational institutions. Review of the school mathematics curriculum conducted by competent teachers in Singapore's secondary schools has become a program research project at the National Institute of Education (NIE) funded by the Ministry of Education (MOE) in Singapore through the Office of Education Research (OER) at NIE. The results helped teachers use "authentic best practices" from local classrooms for critical and meaningful discourse in their programs. The results also contributed to drafting "Mathematical Pedagogy in Secondary Schools of Singapore" [17]. There are suggestions as to how refresher courses for teachers of mathematics can be designed to support their diverse needs in the professional development system [18].

In this article, we focused on the competition of teachers in the form of a Tournament of Methodological Findings in Teaching Geometry to Students. Why geometry? In our opinion, there is a certain contradiction between the important place and role of geometry in the formation and development of the student's personality at school and those superficial ideas about the methods of teaching geometry that future teachers of mathematics may develop in the process of methodological training in the traditional conditions of the educative process in higher education institutions.

Professional analysis of many publications [19-22] 
allows to assert the need for a certain rethinking by teachers of the goals and objectives of teaching geometry at school, and, as a consequence, a certain restructuring of the methodological activities of a teacher of mathematics in teaching geometry to students. Understanding the modern role and place of geometry in the formation and development of the student's personality, readiness and ability to provide appropriate conditions in the learning process of geometry are crucial for the teacher's choice of strategy and tactics of methodological activities [23]. That is why we decided to search for and found new forms of collaboration of teachers of mathematics and those who prepare future teachers of mathematics to improve their method competence in teaching geometry to students. Since 2017, our Tournament of Methodological Findings in Teaching Geometry to Students (Department of Algebra and Mathematics Teaching Methods, nd [24]) has been held annually at Vinnytsia Mykhailo Kotsiubynskyi State Pedagogical University. Our observations suggest that working teachers of mathematics in collaboration with the Pedagogical University have the opportunity for more professional communication, exchange of experience, presentation and recognition of their own original ideas and achievements of methodological activities. The survey of teachers after their participation in the Tournament showed their pleasure of the opportunity to participate in the discussion on topical issues of teaching geometry to students, as well as the pleasure of the opportunity to hear the assessment of their ideas from experts in the field of teaching mathematics.

Episode 2. Considering formation of the foundations of method competence of future teachers of mathematics, we start from the fact that the prerequisite for the methodological self-development of the future teacher of mathematics is the mechanisms of self-acceptance and self-prognosis. Self-acceptance of the future teacher of mathematics is based on a positive attitude to his/her own methodological qualities and achievements. Self-assessment of a future teacher is formed on the basis of the self-acceptance mechanism. Underestimation of one's positive qualities adversely affects the process of methodological growth, as it undermines confidence in one's own strength. A future teacher should be clearly aware of his/her positive and negative features of methodological activities. Our experiment in conducting the Teaching Skill Contest for the best students showed an increased interest of the vast majority of students in teaching science, in the future of methodological activities at school. We noted that some students who won this contest decided on their own aspirations and intentions to study for a master's degree, on the topics of their future qualifying papers, etc.

Certain issues that emerged during our experiment on the organization and conduct of the Teaching Skill Contest may include certain doubts, reluctance of individual students to participate in the Contest. Why should we? Training requires a significant time investment! However, after the Contest, the same students expressed their pleasure of the bright event, of their own attempt to be the best.

Original design of each lesson in accordance with the didactic situation and the content of training, with the goals and cognitive abilities of students of a particular class is now required from the teacher of mathematics in the Ukrainian pedagogical practice. Therefore, an important feature of the methodological activities of a teacher of mathematics in present-day conditions is to update the goals and objectives of such activities.

The possibilities of developing professional competence of working teachers and improving methods and means of formation of professional competence of future teachers have been studied by scientists worldwide. Recently, there was a discussion in America about the Manifesto "Teachers we need and how to get more of them" [3]. A program for professional development of teachers focused on the community of teachers of mathematics has been developed in Korea. Demonstration classes have become a new method of improving the skills of teachers who have voluntarily opened their mathematics classes to members of the community [4]. In China, an approach to improving the methodological activities of teachers of mathematics with the help of a model lesson is quite popular. Features of the content-oriented model lesson are analyzed in detail, and the experience of practical teachers of mathematics involved in the development of a model lesson is studied. The implications of developing model lessons for improving mathematics teaching in China [5] are discussed. The results of comparative research of methodological activities of teachers of mathematics in Germany and China are available. The results of the study showed that German teachers performed better activities related to general pedagogical aspects, while Chinese teachers surpassed their German colleagues in activities related to mathematical training. These results show that social and cultural factors of different countries, such as different philosophical paradigms, traditions of pedagogical education, traditions of teaching mathematics are important factors influencing the professional development of teachers [25]. However, it is possible to identify common trends that can be traced now in different countries in the search for ways to develop the professional competence of working teachers of mathematics and improve the methods and means of formation of professional competence of future teachers of mathematics. First, it is worth highlighting the idea of partnership as a long-term collaboration between teachers and researchers, which is organized to study the constant problems of practice and develop solutions to improve the results of teaching mathematics. The structure of solving the problems of professional development of teachers of mathematics in the settings of partnership allows teachers 
to share common mathematical and pedagogical experience [6].

Contemporary pedagogical science substantiates new research results, which should be the basis for professional self-improvement of teachers of mathematics. Researchers prove that:

- development of educational competencies in the field of education is useful for the professional growth of teachers. Various ways of partnership in scientific and practical activities are relevant [26];

- competent use of information and communication technologies in education in general and in teaching mathematics in particular is relevant. Based on the review of training documents of six "Western" countries (USA, UK, Australia, New Zealand, France and the Netherlands) and eight "Far Eastern" systems (mainland China, Taiwan, Hong Kong, Macao, Japan, South Korea, Singapore and Malaysia), conclusions are made how the use of information and communication technologies impacts improvement in the quality of mathematical education [27];

- important values of teachers as components of their pedagogical identity, and relationship between assigned and implemented values of teachers is also worth of attention [28];

- teachers' professional reading is an understudied aspect of teachers' professional development that remains out of sight, but which has the potential to shape teachers' beliefs and practices [29];

- new reasonable proposals are needed to clarify the content of professional development programs for teachers of mathematics [30].

\section{Conclusions}

There is a well-furnished objective of modernization and improvement of mathematical education, the solution of which is seen by foreign and domestic scientists in the outcome-based approach both in school education and in the system of vocational training [10,31,32,33]. Without downplaying the importance of the scientific heritage of scientists from different countries regarding the possibilities of collaboration between teachers of mathematics, as well as forms, methods and means of their professional development, we, on the basis of our own experimental studies, conclude that participation of teachers of mathematics and future teachers of mathematics in competitions with colleagues can positively affect the formation and development of competence in teaching mathematics. This requires a system of motivation of teachers and students to participate in such competitions and a special, well-thought-out preparation of such competitions. Partnership of teachers of mathematics and teachers of higher educational institutions who prepare future teachers of mathematics in the preparation and conduct of such competitions is mutually beneficial.

\section{REFERENCES}

[1] Beswick, K. (2012). Teachers' beliefs about school mathematics and mathematicians' mathematics and their relationship to practice. Educational Studies in Mathematics, 79(1), 127-147. https://doi.org/10.1007/s10649-011-9333-2

[2] Nagach M.V. (2008) Pidhotovka maibutnikh uchyteliv u shkolakh profesiinoho rozvytku v SShA [Future Teachers' Preparation in the Professional Development Schools of the USA]. Extended abstract of candidate's thesis. Kyiv: The Education Management University of the Academy of Pedagogical Sciences of Ukraine.[in Ukrainian].

[3] Back S. (2012) Preparing (Pseudo) Professional. In: Back S. (eds) Ways of Learning to Teach. SensePublishers, Rotterdam, 101-128. Doi https://doi.org/10.1007/978-94-6091-852-0_6

[4] Kwon O.N., Park J.H., Park J.S., Park J. (2017) A Community-Based, Practice-Oriented Teacher Professional Development Program: Changes in Teaching Culture in Korea. In: Kaur B., Kwon O., Leong Y. (eds) Professional Development of Mathematics Teachers. Mathematics Education - An Asian Perspective. Springer, Singapore

[5] Huang, R., \& Li, Y. (2014). Developing high-leverage practices in mathematics through exemplary lesson development: A Chinese approach. In Y. Li, E. Silver, \& S. $\mathrm{Li}$ (Eds.), Transforming mathematics instruction-Multiple approaches and practices (pp. 231-254). New York: Springer.

[6] Roth, KJ, Bintz, J., Wickler, Kathleen J. Roth, Jody Bintz, Nicole I. Z. Wickler, Connie Hvidsten, Joseph Taylor, Paul M. Beardsley, Arlo Caine \& Christopher D. Wilson Design principles for effective video-based professional development. IJ STEM Ed (2017) 4: 31.https://doi.org/10.1186/s40594-017-0091-2

[7] Wininng Widiharti, Burhanuddin Tola , Yetti Supriyat . Evaluation of Principal Partnership Programs in the Directorate of Education Management - The Application of Kirkpartick and Countenance Stake Evaluation Model. Universal Journal of Educational Research 7.9A (2019) 71 - 77. doi: 10.13189/ujer.2019.071609.

[8] Geri Salinitri, Stephanie Palazzolo, Ruxandra Nahaiciuc, Emilia Iacobelli, Yuanrong Li, George Zhou . Analysis of Canadian Inquiry-based Science Teaching Practices and its Implications for Reciprocal Learning. Universal Journal of Educational Research 6.10 (2018) 2280 - 2293. doi: 10.13189/ujer.2018.061027.

[9] Valoyes-Chávez, L. On the making of a new mathematics teacher: professional development, subjectivation, and resistance to change. Educ Stud Math (2019) 100: 177. https://doi.org/10.1007/s10649-018-9869-5

[10] Schwarts, G. \& Karsenty, R. "Can this happen only in Japan?": mathematics teachers reflect on a videotaped lesson in a cross-cultural context. J Math Teacher Educ 
(2019). https://doi.org/10.1007/s10857-019-09438-z

[11] Jacobs, J., Seago, N. \& Koellner, K. Preparing facilitators to use and adapt mathematics professional development materials productively. IJ STEM Ed (2017) 4: 30. https://doi.org/10.1186/s40594-017-0089-9

[12] Robutti, O., Cusi, A., Clark-Wilson, A. et al. ICME international survey on teachers working and learning through collaboration: June 2016. ZDM Mathematics Education $\quad$ (2016) 651. https://doi.org/10.1007/s11858-016-0797-5

[13] Santagata, R. \& Yeh, C. Learning to teach mathematics and to analyze teaching effectiveness: evidence from a videoand practice-based approach. J Math Teacher Educ (2014) 17: 491. https://doi.org/10.1007/s10857-013-9263-2

[14] Matiash, O.I., \& Mykhailenko, L.F. (2015). Psychological and pedagogical bases of formation of professional competence of the future teacher. Scientific journal of the Volodymyr Vynnychenko Central Ukrainian State «Scientific notes. Series: Pedagogical Sciences» 141(1), 132-136.

Retrieved fromhttps://www.cuspu.edu.ua/images/nauk_zapiski/pedag ogy/141_1.pdf.[in Ukrainian]

[15] Online Available: Department of Algebra and Mathematics Teaching Methods. (nd). About the Olympics. Online available http://amnm.vspu.edu.ua/olymp/olymp-about/

[16] Online Available: Department of Algebra and Mathematics Teaching Methods. (nd). Contest of Methodical mastership. Online available from http://amnm.vspu.edu.ua/konkurs-metod-maysternosti-201 9/\#more-3086W

[17] Tay E.G., Lim S.K., Ho W.K., Toh T.L. (2017) Preparing Mathematics Teachers in Singapore: The Issue of Mathematics Content Knowledge. In: Tan OS., Liu WC., Low EL. (eds) Teacher Education in the 21st Century. Springer, Singapore

[18] Kuzle, A. \& Biehler, R. Examining mathematics mentor teachers' practices in professional development courses on teaching data analysis: implications for mentor teachers' programs. ZDM Mathematics Education (2015) 47: 39. https://doi.org/10.1007/s11858-014-0663-2

[19] Laborde C. (2015) Teaching and Learning Geometry. In: Cho S. (eds) The Proceedings of the 12th International Congress on Mathematical Education. Springer, Cham

[20] Cheah U.H., Herbst P.G., Ludwig M., Richard P.R., Scaglia S. (2017) Topic Study Group No. 13: Teaching and Learning of Geometry-Secondary Level. In: Kaiser G. (eds) Proceedings of the 13th International Congress on Mathematical Education. ICME-13 Monographs. Springer, Cham

[21] Hwang WY., Ochirbat A., Lin LK. (2016) Exploring Ubiquitous Geometry Learning in Real Situation. In: Spector M., Lockee B., Childress M. (eds) Learning, Design, and Technology. Springer, Cham

[22] Sinclair N. et al. (2017) Geometry Education, Including the Use of New Technologies: A Survey of Recent Research. In: Kaiser G. (eds) Proceedings of the 13th International Congress on Mathematical Education. ICME-13
Monographs. Springer, Cham

[23] Matiash, O.I. (2013). Theoretical and methodological bases of formation of method competence of the future teacher of mathematics for teaching geometry to students: monograph. Sole Proprietor Lehkun V.M. .[in Ukrainian]

[24] Online Available: Department of Algebra and Mathematics Teaching Methods. (nd). Olympiad-2019. Online available from http://amnm.vspu.edu.ua/olymp/olimpiada-2019/

[25] Zhang, Y., \& Hao, C. (2016). Comparative Study of In-service Teacher Education between China and Germany. Educational Process: International Journal, 5(3), 212-222

[26] Koichu, B. \& Pinto, A. Developing Education Research Competencies in Mathematics Teachers Through TRAIL: Teacher-Researcher Alliance for Investigating Learning. Can J Sci Math Techn (2018) 18: 68.https://doi.org/10.1007/s42330-018-0006-3

[27] Wong NY. (2003) The Influence of Technology on the Mathematics Curriculum. In: Bishop A.J., Clements M.A., Keitel C., Kilpatrick J., Leung F.K.S. (eds) Second International Handbook of Mathematics Education. Springer International Handbooks of Education, vol 10. Springer, Dordrecht

[28] Beswick, K., Teachers' Beliefs That Matter in Secondary Mathematics Classrooms. Educ Stud Math (2007) 65: 95. https://doi.org/10.1007/s10649-006-9035-3

[29] Foster, C. \& Inglis, M. Mathematics Teacher Professional Journals: What Topics Appear and How Has This Changed over Time? Int $J$ of Sci and Math Educ (2018).https://doi.org/10.1007/s10763-018-9937-4

[30] Prediger, S., Quasthoff, U., Vogler, AM. et al. How to Elaborate What Teachers Should Learn? Five Steps for Content Specification of Professional Development Programs, Exemplified By "Moves Supporting Participation in Classroom Discussions". J Math Didakt (2015) 36: 233. https://doi.org/10.1007/s13138-015-0075-z

[31] Zeynep Doğan . Assessing the Teaching Practice Processes of Preservice Teachers and Their Competencies of Mathematics Teaching within the Scope of Teaching Practice Course. Universal Journal of Educational $\begin{array}{llllll}\text { Research } & 7.1 & \text { (2019) } & 171 & \text { - } & 177 .\end{array}$ 10.13189/ujer.2019.070122.

[32] Lewis, C.C., Perry, R.R. \& Hurd, J. Improving mathematics instruction through lesson study: a theoretical model and North American case. J Math Teacher Educ (2009) 12: 285. https://doi.org/10.1007/s10857-009-9102-7

[33] Schoenfeld, A.H., Thomas, M. \& Barton, B. On understanding and improving the teaching of university Mathematics. IJ STEM Ed (2016) 3: 4.https://doi.org/10.1186/s40594-016-0038-z 